\title{
Educational Tours as a Learning Tool to the Third Year Tourism Students of De La Salle University- Dasmarinas
}

\author{
Jackqueline E. Uy*, Hannah Miriam Verano, Chrysler Luis B. Verbo, Gueco, Irene \\ Philippines
}

*Corresponding Author: Jackqueline E. Uy, Philippines

\begin{abstract}
Educational tours are part of the curriculum of the College of Tourism and Hospitality Management, De La Salle University-Dasmarinas. They are highly significant to the students especially Tourism students. The purpose of this study was to determine how effective educational tours were as a learning tool using the Experiential Learning Theory by David Kolb. This study determined the demographic profile of the third year tourism students in terms of gender, section, educational tours joined and monthly family income and lastly, this study determined if there is a significant difference between the demographic profile of the respondents and their assessment of educational tours as a learning tool. The researchers used exploratory research design with the third year students of the Bachelor of Science in Tourism Management as the population size and used random sampling method. The researchers made a survey questionnaire and utilized statistical tools such as weighted mean, frequency distribution, percentage, standard deviation, T-test and ANOVA. It is recommended that The college must organize tours that will expose students to experience foreign culture, historical sites, riding different modes of transportation, more activities that will engage the students to reflect and interact with the locals, seminars that would emphasize on the skills, and attitude of those in the tourism profession in that educational tour, allowing the students to use their knowledge when planning their own itinerary, it should be an affordable educational tour for students that have limited financial resources.
\end{abstract}

Key words: Educational Tours, Experiential Learning Theory, De La Salle University Dasmarinas, CTHM, Tourism.

\section{INTRODUCTION}

Educational tours are a learning experience. They are vital for tourism students because through this, they acquired authentic experience and gained valuable knowledge that they can utilize in their future endeavors. The skills that they observed from the people and tourism professionals they encountered during these tours helped them as they reflected upon their learnings. The purpose of these tours was to broaden the skills and abilities of tourism students for their future work in the industry.

Educational tour allowed student to witness a new environment while learning in their own pace, this kind of learning tool didn't involve textual or abstract presentation instead it stimulated the mind and engaged the students. (Kamat, 2018). Martin (2019) mentioned the advantages of having an educational tour which were communicating with locals in which students would learn the culture, of the destinations from the perspective of the locals, talking with people would help the student be more aware of the local customs, beliefs, and values. Students are expose to different culture when going to educational tours which offers opportunities and experiences that student can reflect upon to apply what they have learned in real-life situations. If students experience educational tour, it can broaden their understanding of themselves and of the world, being more aware of oneself and realize what their passion is about. When students are exposed to different places for the first time that can be aware of issues like environmental, socioeconomic, and political that can lead to an intellectual discussion between the students themselves and have a conclusion on their own. According to the Commission of Higher Education Memorandum Order No. 63 Series of 2017 Article V (2017), Educational Tour refers to off-campus learning activities involving mobility of student with the supervision of authorized personnel outside the premises of the institution which lasts for more than one (1) day and involves relatively more places of destination than a field trip in accordance with specific degree program requirements. 
International educational tours allow student to be able to improve their current skills, be expose to other heritage, culture, language, destinations, and foreign people, develop confidence and selfesteem, gain experience, and have opportunities in their career path, be adaptable to changes and when returning home what they had learned or experienced can be used for their future and in the society. (Kamat, 2018). Stuart (n.d.) believed that international educational tour has a positive impact to the learning experience, tacit knowledge and problem-solving skills of the students. The advantages of participating in educational tours that are international are improved critical thinking skills, experiential learning happens, expansion of worldview, reinforce of classroom material, stronger teacher-student relationships, build confidence, increased motivation in the classroom, all students benefits and lifelong memories. Analyzing information, systematically solve problems, innovative solutions, plan strategically while thinking creatively are examples of critical thinking which most employers prioritize in the tourism industry, student who participated in real-life experiences while on international educational tour have the chance to hone their critical thinking skills, learning concept are applied to real-life circumstances, students are more able to recall what they have learn in classroom which is when experiential learning happens in educational tours, students are encourage to explore different culture when going to destinations in educational tours which affects the personal beliefs, values and attitudes of a student on how they perceive, think, feel and do things, by having students apply what they have learned in classroom to actual experience, they will understand the value and deepening the knowledge about the learning concepts, teachers and students would have to interact during educational tours which would encourage more intellectual interaction between them, travelling abroad without family member or guardian will help to boost the confidence of a student by stepping out in their comfort zone and challenge themselves to what they are capable of, the use of seminars, workshops or seeing the possible professions in the future can help to increase the motivation to learn of a student, all students will benefit when attending educational tours internationally due to the certain objectives of the tour that will be educational, while the memories and experiences that would be achieved during the international educational tours can be an opportunities for the students in their career path.

De La Salle University-Dasmarinas started to offer Tourism and Hospitality Management Program since 2000 and they started to offer educational tours in 2001. As part of the university's program is to expose the Tourism students to their chosen profession, there are the Major Course Subjects that are related to educational tours. For Asia Pacific Tourism, Geography, and Culture, the students were asked to create a reaction video about a chosen cultural aspect of Taiwan and they were also asked to record a tour guiding video during their Taiwan Tour. For Western Tourism, Geography and Culture, Transportation Management, the students were asked to discuss at least one aspect of culture (i.e. architecture, food, language, etc.) that can be seen or experienced while in Petite France, a tourist destination in South Korea. Another one of their tasks was to create a Flipgrid Video about any western cultural aspect that they have seen or experienced during their South Korea Tour. For Transportation Management (W/ Tourism Transport Paradigm), the students were asked to journal about their transportation experience in South Korea. They should have experienced air, land and sea transportation.

The school offers both international and domestic educational tours but this study had focus on the international tours namely Taiwan, and South Korea. The researchers want to determine the effectiveness of educational tours as a learning tool to the third-year tourism students of De La Salle University Dasmarinas, Cavite. In order to do so, Experiential Learning Theory was being applied to this study. Many studies have been done about educational tours. However, there has not been a study done on the effectiveness of educational tours as a learning tool, specifically on the third-year students of the College of Tourism and Hospitality Management, De La Salle University Dasmarinas.

This study mainly focuses on determining the effectiveness of educational tours as a learning tool to the 3rd year tourism students of De La Salle University Dasmarinas, Cavite. This research aims to achieve the following objectives:

1. To determine the demographic profile of the 3rd year tourism students in terms of:

- Gender, 
- Section,

- $\quad$ Educational tours joined

- $\quad$ Monthly family income

2. To determine the effectiveness of educational tours as a learning tool in terms of:

- $\quad$ Active Experimentation

- $\quad$ Concrete Experience

- $\quad$ Reflective Observation

- Abstract Conceptualisation

3. To determine if there is a significant difference between the demographic profile of the respondents and their assessment of the effectiveness of educational tours as a learning tool.

This study focuses on the effectiveness of educational tours as a learning tool to the third year tourism students of De La Salle University Dasmarinas. This study limits its coverage on the third year Tourism students only and only the international tours such Taiwan and South Korea will be covered. The data collection will be conducted to 105 randomly selected third year tourism students of the present school year 2021-2022 who will represent the population. This study considers the demographic profile of the students such as gender, section, educational tours joined and family income and if that has a significant difference with their assessment of educational tours. Each of the respondents were given the same questionnaire to answer.

The findings of this study would be helpful to the students because they will know the effectiveness of educational tours as a learning tool and they will learn to appreciate College of Tourism and Hospitality Management more. Hopefully, the findings in this study will help professors in improving future tour journal outputs of the tourism students. This study would be beneficial to future researchers because they can get some information that they might need in their research related to this topic.

\section{Literature REVIEW AND CONCEPTUAL/THEORETICAL FRAMEWORK}

The experiential learning theory was developed by David Kolb in the year 1984. Barton (2020) states that "learning involves the acquisition of abstract concepts that can be applied flexibly in a range of situations. In Kolb's Experiential Learning Theory, the impetus for the development of new concepts is provided by a new experience. He, therefore, states that learning is the process whereby knowledge is created through the transformation of experience." There are four stages in Kolb's experiential learning theory, namely: concrete experience, reflective observation, abstract conceptualization and active experimentation. The student learns effectively if they progress through the cycle completely, but the cycle can also be entered at any stage. (McLeod, 2017 \& Mcpheat, 2017)

During the concrete experience stage, the student is actively engaged or involved in an activity or task. During the reflective observation stage, the student is reflecting upon the task. This is when the learner is asking questions and discussing the experience with his or her companions. Next is the abstract conceptualization stage. During this stage, "The learner attempts to draw conclusions of the experience by reflecting on their prior knowledge, using ideas with which they are familiar or discussing possible theories with peers." (Kurt, 2020). The students begin classifying concepts and start comparisons with their understanding of the activity or task. The last stage is the active experimentation stage and in this stage the learner starts to apply what they have learned from the activity or task. According to Kurt (2020) "learners return to participating in a task, this time with the goal of applying their conclusions to new experiences."

Suarez et. al (2017) did a study about the effectiveness of educational tours but the difference is that the respondents were $4^{\text {th }}$ year students in College of Tourism and Hospitality Management in Lyceum of the Philippines, Batangas City. Several literatures have claimed that experiential learning is a highly effective teaching and learning tool. Mechanical engineering students were able to go through the four stages of Kolb's experiential learning theory during their mechanical design course and 
because of that they were able to deeply process their experience and acquire knowledge. (Li, et al., 2019). Widyastuti et al. (2019) conducted a survey research in Jawa Tengah, Indonesia where they were interested in implementing experiential learning. They found out that the students "were very enthusiastic and motivated" with the experiential learning activities they did. Ahad (2017) did a study in Ethiopia about applying Kolb's theory in teaching architecture. He concluded that the students learned better when they were able to apply what they learned. McPherson-Geyser, Villiers \&Kavai (2020) claim that implementing experiential learning in schools give many advantages to learning especially in teaching Life Sciences. This learning theory also enhances and skills and attitudes of students effectively (Idris, Din \&Tajuddin, 2020). The findings in a study done by Gorghiu and Santi (2016) suggested that this theory highly stimulates the minds of the students to learn something. In the study by Giac, Gai, \& Hoi (2017), experiential learning activities were organized to teach science for general education in Vietnam. The results of the study indicate that hands-on learning activities will definitely teach students applicable knowledge, skills and reinforce positive learning.

There are plenty of benefits to applying the experiential learning theory. Barton (2020) claims that it helps learners "develop a positive attitude towards learning" and Wingston (2020) states that it is highly immersive and engaging for everyone wanting to learn and it gives much confidence to the student because they are able to demonstrate what they have learned. Kerner (2018) states that this learning theory promotes communication skills and teamwork. Bleich (n.d.). believes that it connects the gap between practice and theory of a task. Lastly, the experiential learning theory allows the learners to develop their problem-solving skills creatively. (Stuart, 2020).

This study is anchored upon the experiential learning theory. The researchers believe that utilizing this learning theory will aid them greatly in determining the effectiveness of educational tours as a learning tool to the 3rd year tourism students of De La Salle University Dasmarinas, Cavite.

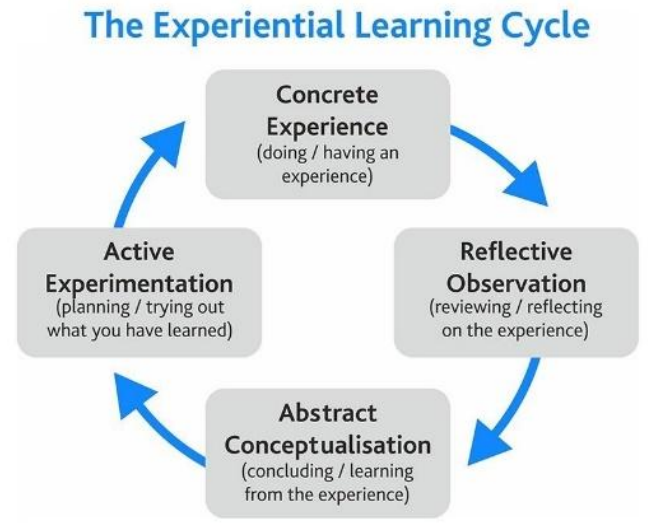

Figure1. Experiential Learning Theory

\section{MethodologY}

This quantitative research had used historical research design. This kind of research design complimented our research paper that used the previous experienced of the respondents that joined. The objective of the study was to see the effectiveness of the educational tours as a learning tool to the third year tourism students of the De La Salle UniversityDasmarinas that required an attendanced from the respondents in the previous international educ ational tours.

The participants of the study were the third-year tourism students of the De La Salle UniversityDasmarinas. The sampling frame of the researchers were the list of all the third-year students of the said college. The sampling method used was probability sampling method, specifically the simple random sampling. The researchers followed the recommendation of the statistician with the sample size of 105 . The populatio $\mathrm{n}$ size of this study was 115 .

The research instrument used in the study was a survey questionnaire made by the researchers that had been validated by the statistician. The first part of the survey questionnaire contained the demographic profile of the respondents, which included gender, section, educational tours joined and monthly family income. The second part of the questionnaire contained the questions about 
determining the effectiveness of educational tours as a learning tool in terms of Active Experimentation, Concrete Experience, Reflective Observation and Abstract Conceptualisation. The second part used 4-point Likert Scale where 4 means strongly agree and 1 means strongly disagree.

This data gathering process was conducted online because the students and the researchers could not come to school because of the pandemic. The researchers used Google Forms and they were the ones who distributed it to the respondents one by one at the same time requested the class president of each section to send the survey questionnaires to the group chat. They shared the link of the said Google Forms to the respondents by the month of March when the data gathering took placed and during weekdays via Facebook messenger. After the collecting the data the respondents compiled and transferred to Microsoft excel spreadsheet software that was sent to the statistician. After receiving the receipt that proved the payment of the researchers the result was then sent to the leader of the researchers after was the finalization of the research paper.

Frequency and percentage were used to determine the demographic profile of the 3rd year tourism students in terms of gender, educational tours joined and family income. Mean and standard deviation were used to determine the effectiveness of educational tours as a learning tool. The standard weighted mean had a meaning for the corresponding points 3.50-4.00 Strongly Agree or Highly Effective, 2.50-3.49 Agree or Effective, 1.50-2.49 Disagree or Somewhat effective, and 1.00-1.49 Strongly disagree Not effective. T-test and Analysis of Variance or ANOVA were used to determine if there is a significant difference between the demographic profile of the respondents and their assessment of the effectiveness of educational tours as a learning tool. The result from the survey questionnaires were done by the serviced of the statistician.

The ethical consideration that the researchers used focused on 4 qualifications of the participants in this study: (1) must not be below 18 years old; (2) must not be a person with disabilities (PWD); (3) must not be indigenous person and (4) must be a bonafide third year student at College of Tourism and Hospitality Management, De La Salle University Dasmariñas. The stated ethical consideration was then observed by the researchers before sharing the survey questionnaires.

\section{RESUlts AND DiscusSiONS}

You start by giving one paragraph that introduces the data you are about to present. For example, if you are determining the profile of the respondent, you may start by stating: "The first part of the study examines the profile of the respondents. The variables examined were age and highest educational attainment. Table 1 shows the frequency and percentage of the respondents' age." The information found at the table should be sufficient enough that the reader do not need to read the succeeding or preceding paragraphs to understand. There is no need to put into words whatever is found at the tables. Make sure that tables are not cut (i.e. table covers two columns or two pages). There are no specific rules that says you have to put the table after or before a discussion paragraph. But in most journals, the discussion happens before the table is presented.

TABLE1. Distribution of the Respondents Based on Their Gender

\begin{tabular}{|l|l|l|}
\hline Gender & Freq & Percentage \\
\hline Female & 53 & 50.48 \\
\hline Male & 52 & 49.52 \\
\hline Total & 105 & 100 \\
\hline
\end{tabular}

The demographic profile of the respondents in Table 1 shows the gender of the respondents. The table showed that most of the respondents were female, corresponding to $50.48 \%$. While the male respondents correspond to $49.52 \%$. The percentages of both genders are not far apart, indicating that the respondents were equally answered by both genders. For the tourism sector, the impact of greater gender equality and women's empowerment would be highly beneficial, because diverse and gender equitable organizations perform better, UNWTO (2020).

TABLE2. Distribution of the Respondents based on their Section

\begin{tabular}{|l|l|l|}
\hline Section & Freq & Percentage \\
\hline BTM3-1 & 27 & 25.71 \\
\hline BTM3-2 & 29 & 27.62 \\
\hline
\end{tabular}


Educational Tours as a Learning Tool to the Third Year Tourism Students of De La Salle UniversityDasmarinas

\begin{tabular}{|l|l|l|}
\hline \multicolumn{2}{|l|}{} \\
\hline BTM3-3 & 24 & 22.86 \\
\hline BTM3-4 & 25 & 23.81 \\
\hline Total & 105 & 100 \\
\hline
\end{tabular}

The demographic profile of the respondents in Table 2 shows the section of the respondents. The table showed that most of the respondents were from BTM3-2 which corresponds to $27.62 \%$, followed by BTM3-1 which corresponds to $25.71 \%$, then BTM3-4 which corresponds to $23.81 \%$ and lastly, from BTM3-3 which corresponds to $22.86 \%$. The numbers of respondents from different sections were not too far from each other, meaning that all the four sections participated well in the survey.

TABLE3. Distribution of Respondents based on their Educational Tours Joined

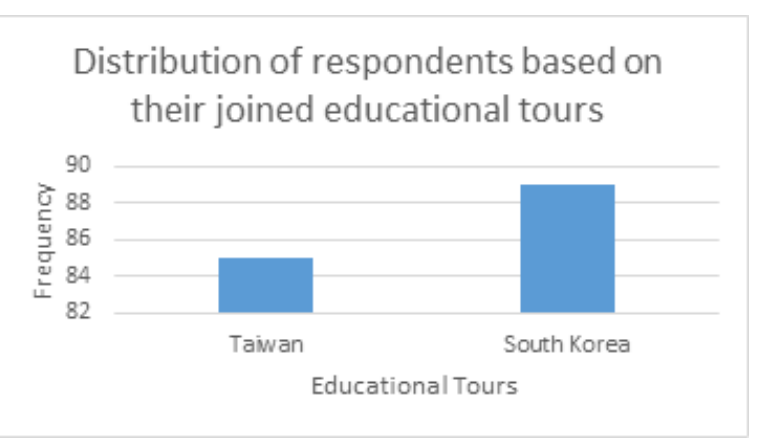

The demographic profile of the respondents in Table 3 shows the educational tours joined by the respondents. The table showed that most of the respondents joined the South Korea tour rather than the Taiwan tour. Meaning, the South Korea tour is much more effective as a learning tool compared to the Taiwan tour and this result, it can highly encourage the university to have this kind of tour every academic year. While South Korea might not yet be the number one travel destination for many around the world, there are plentiful reasons why you should visit the country of the morning calm on your next vacation. From history to culture and food to religion, Dunsmore (2017).

TABLE4. Distribution of the Respondents based on their Family's Monthly Income

\begin{tabular}{|l|l|l|}
\hline Family Monthly Income & Freq & Percentage \\
\hline P5000 - P10000 & 2 & 1.90 \\
\hline P10001 - P15000 & 6 & 5.71 \\
\hline P15001 - P20000 & 7 & 6.67 \\
\hline P20001 and above & 90 & 85.71 \\
\hline Total & 105 & 100 \\
\hline
\end{tabular}

The demographic profile of the respondents in Table 4 shows the family's monthly income of the respondents. The table showed that most of the respondent's family income is 20,001 and above, which corresponds to $85.71 \%$, followed by between 15,001 and 20,000 which corresponds to $6.67 \%$, then between 10,001 to 15,000 which corresponds to $5.71 \%$. On the other hand, family monthly incomes between 5,000 to 10,000 was the least percentage, which corresponds to $1.90 \%$. Meaning that most of the respondents join educational tours because they have sufficient funds for the tour. According to PSA (2018), the national average of family income is P313.348 per year or P26,112 per month.

The second part of this study examines the assessment of the respondents of educational tours as a learning tool to the Experiential Learning Theory. It is composed of 4 parts namely; Active Experimentation, Concrete Experience, Reflective Observation and Abstract Conceptualisation.

TABLE5. Respondents Assessment of Educational Tours as Learning Tool in Terms of Active Experimentation

\begin{tabular}{|l|c|c|c|}
\hline Active Experimentation & Mean & Std.Dev & Interpretation \\
\hline $\begin{array}{l}\text { 1. I was able to use the skills or abilities I have acquired from } \\
\text { the educational tour/s. }\end{array}$ & 3.57 & 0.59 & Strongly agree \\
\hline $\begin{array}{l}\text { 2. I was able to apply the obtained experience from the } \\
\text { educational tour/s. }\end{array}$ & 3.57 & 0.53 & Strongly agree \\
\hline $\begin{array}{l}\text { 3. I was able to determine the effectiveness of educational } \\
\text { tour/s on my course. }\end{array}$ & 3.61 & 0.55 & Strongly agree \\
\hline
\end{tabular}


Educational Tours as a Learning Tool to the Third Year Tourism Students of De La Salle UniversityDasmarinas

\begin{tabular}{|l|c|c|c|}
\hline $\begin{array}{l}\text { 4. I was able to plan my future endeavors based on what I have } \\
\text { learned from educational tour/s. }\end{array}$ & 3.56 & 0.55 & Strongly agree \\
\hline $\begin{array}{l}\text { 5. I have plan for my free time of during the educational tour. } \\
\text { 6. I have practiced what I have learned in the educational tour/s }\end{array}$ & 3.60 & 0.53 & Strongly agree \\
\hline on the classroom. & 3.42 & 0.60 & Agree \\
\hline $\begin{array}{l}\text { 7. I was able to apply what I learned in the educational tour/s } \\
\text { on daily activities. }\end{array}$ & 3.42 & 0.57 & Agree \\
\hline $\begin{array}{l}\text { 8. I think the educational tour/s was/were helpful for my future } \\
\text { lareer in the Tourism Industry. }\end{array}$ & 3.65 & 0.50 & Strongly agree \\
\hline $\begin{array}{l}\text { 9. I have learned something related to my future profession } \\
\text { from the educational tour/s. }\end{array}$ & 3.62 & 0.54 & Strongly agree \\
\hline $\begin{array}{l}\text { 10. I was able to answer the tour journal based on the } \\
\text { educational tour/s. }\end{array}$ & 3.70 & 0.48 & Strongly agree \\
\hline Overall Mean & $\mathbf{3 . 5 7}$ & Highly Effective \\
\hline
\end{tabular}

3.50-4.00 Strongly Agree / Highly Effective, 2.50-3.49 Agree / Effective, 1.50-2.49 Disagree / Somewhat effective, 1.00-1.49 Strongly disagree / Not effective

Table 5 shows the Respondents Assessment of Educational Tours as Learning Tool in Terms of Active Experimentation. In terms of Active Experimentation, the highest mean obtained is the item number 10 which is "I was able to answer the tour journal based on the educational tour/s." This number obtained the highest mean 3.70 with a standard deviation of 0.48 . This means that the students place a high value on the tour journals given after the educational tours. The tour journals test the knowledge and experience of the respondents and it also makes them reflect upon the tour they experienced.

Item number 8 is the highest mean next to number 10, that is interpreted as a Strongly Agree. It is " I think the educational tour/s was/were helpful for my future career in the Tourism Industry" and the mean of it is 3.65 with a standard deviation of 0.50 . This means that the respondents truly view that educational tours are helpful for their future career in the tourism industry and they strongly agree with the statement. Item number 9 is "I have learned something related to my future profession from the educational tour/s" and it has a mean of 3.62 with a standard deviation of 0.54 .

However, the least mean obtained is item number 6 which is "I have practiced what I have learned in the educational tour/s on the classroom." It has a mean of 3.42 and a standard deviation of 0.60 that is interpreted as Agree.

According to Lanier (2017), "Students in all disciplines need a strong understanding of theory, research, and practical skills. The combination of these three knowledge areas provides skill sets, work, expertise, and a knowledge base that a work-ready graduate can use in diverse circumstances, both international and domestic." The respondents were able to apply what they have learned and experienced in educational tours to daily activities and the educational tours were helpful to their future career in the tourism industry thus able to be used active experimentation.

The overall mean for table 5 is 3.57 which is interpreted as Highly Effective. This means that Active Experimentation aspect is a highly effective learning tool for educational tours.

TABLE6. Respondents Assessment of Educational Tours as Learning Tool in Terms of Concrete Experience

\begin{tabular}{|l|c|c|c|}
\hline Concrete Experience & Mean & Std.Dev & Interpretation \\
\hline $\begin{array}{l}\text { 1. I have observed how the protocols have been followed during } \\
\text { the educational tour/s such as checking in hotel etc. }\end{array}$ & 3.59 & 0.55 & Strongly agree \\
\hline $\begin{array}{l}\text { 2. I have experienced interacting with locals during the educational } \\
\text { tour/s. }\end{array}$ & 3.60 & 0.58 & strongly agree \\
\hline $\begin{array}{l}\text { 3.I have interacted with student/s outside my section during the } \\
\text { educational tour/s. }\end{array}$ & 3.49 & 0.77 & agree \\
\hline $\begin{array}{l}\text { 4. I have seen jobs related to Tourism industry during the } \\
\text { educational tour/s like tour guiding, hotel receptionist etc. }\end{array}$ & 3.67 & 0.53 & strongly agree \\
\hline 5. I have learned something during the educational tour/s. & 3.67 & 0.53 & strongly agree \\
\hline 6.I have observed the culture of the destinations during educational & 3.69 & 0.47 & strongly agree \\
\hline
\end{tabular}


Educational Tours as a Learning Tool to the Third Year Tourism Students of De La Salle UniversityDasmarinas

\begin{tabular}{|l|c|c|c|}
\hline \multicolumn{2}{|l|}{} & & \\
\hline tour/s. & 3.68 & 0.49 & strongly agree \\
\hline 7.I visited a historical place during the educational tour/s. & 3.63 & 0.50 & strongly agree \\
\hline $\begin{array}{l}\text { 8. I experienced the different transportation systems during the } \\
\text { educational tour/s. }\end{array}$ & 3.70 & 0.46 & strongly agree \\
\hline $\begin{array}{l}\text { 9. I have experienced the difference of learning between classroom } \\
\text { and in educational tour/s. }\end{array}$ & 3.77 & 0.47 & strongly agree \\
\hline 10.I had fun during the educational tour/s. & \multicolumn{2}{|c|}{$\mathbf{3 . 6 5}$} & highly effective \\
\hline Overall mean
\end{tabular}

3.50-4.00 Strongly Agree / Highly Effective, 2.50-3.49 Agree / Effective, 1.50-2.49 Disagree / Somewhat effective, 1.00-1.49 Strongly disagree / Not effective

Table 6 shows the Respondents Assessment of Educational Tours as Learning Tool in Terms of Concrete Experience. In terms of Concrete Experience, the highest mean obtained is 3.77 which is item number 10 and it is "I had fun during the educational tour/s." This means that the respondents truly enjoyed the educational tours and they strongly agree with the statement. Next to the item number 10 is item number 9 with a mean of 3.70 and a standard deviation of 0.46 . This can be interpreted as Strongly Agree. Item number 9 is "I have experienced the difference of learning between classroom and in educational tour/s." Item number 6 is "I have observed the culture of the destinations during the educational tour/s" and it has mean of 3.69 with a standard deviation of 0.47 which can be interpreted as Strongly Agree.

However the item number with the least mean is 3 because it has a mean of 3.49 and a standard deviation of 0.77 which can be interpreted as Agree. Item number 3 is "I have interacted with student/s outside my section during the educational tour/s."

According to Educating Adventure (n.d.) "Students may struggle to grasp concepts that don't pertain to the "real world." With experiential learning, students are given the opportunity to apply data and ideas in a real-world situation where they too play an active role. As the student interacts with the information, it becomes real to them" The respondents were able to be involved in a task that required them to interact with the locals in the destinations of the educational tours.

The overall mean is 3.65 which can be interpreted as Highly effective.

TABLE7. Respondents Assessment of Educational Tours as Learning Tool in Terms of Reflective Observation

\begin{tabular}{|l|c|c|c|}
\hline Reflective Observation & Mean & Std.Dev & Interpretation \\
\hline $\begin{array}{l}\text { 1. I was able to understand the purpose and objectives of the } \\
\text { educational tour/s. }\end{array}$ & 3.65 & 0.50 & strongly agree \\
\hline $\begin{array}{l}\text { 2. I was able to experience their local foods. } \\
\text { 3. I was able to develop a deeper appreciation on the culture of the } \\
\text { country. }\end{array}$ & 3.68 & 0.51 & strongly agree \\
\hline 4. I was able to evaluate the tourism resources of the destination. & 3.49 & 0.49 & strongly agree \\
\hline $\begin{array}{l}\text { 5. I was able to report sustainable tourism practices in the tourism } \\
\text { industry. }\end{array}$ & 3.46 & 0.67 & agree \\
\hline $\begin{array}{l}\text { 6. I was able to assess the different profession in the Tourism } \\
\text { Industry. }\end{array}$ & 3.55 & 0.55 & strongly agree \\
\hline $\begin{array}{l}\text { 7. I was able to have a reflection about what I experienced during } \\
\text { the educational tour/s. }\end{array}$ & 3.58 & 0.57 & strongly agree \\
\hline $\begin{array}{l}\text { 8. I was able to discover a problem from a visited destination in the } \\
\text { educational tour/s. }\end{array}$ & 3.44 & 0.62 & agree \\
\hline $\begin{array}{l}\text { 9. I was able to reflect what are the skills and attitude of those in } \\
\text { the Tourism Industry during the educations tour/s }\end{array}$ & 3.57 & 0.53 & strongly agree \\
\hline $\begin{array}{l}\text { 10.I was able to observe the guidelines, and rules that had happen } \\
\text { during the educational tour/s. }\end{array}$ & 3.61 & 0.51 & strongly agree \\
\hline Overall mean & \multicolumn{2}{|c|}{$\mathbf{3 6}$} & highly effective \\
\hline
\end{tabular}

3.50-4.00 Strongly Agree / Highly Effective, 2.50-3.49 Agree / Effective, 1.50-2.49 Disagree / Somewhat effective, 1.00-1.49 Strongly disagree / Not effective 
Table 7 shows the Respondents Assessment of Educational Tours as Learning Tool in Terms of Reflective Observation. In terms of Reflective Observation, the item number with the highest mean is item number 2 which is "I was able to experience their local foods." It has a mean of 3.68 and a standard deviation of 0.51 which can be interpreted as Strongly Agree. Next to item number 2 is item number 1 which is "I was able to understand the purpose and objectives of the educational tour/s." It has a mean of 3.65 and a standard deviation of 0.50 which can be interpreted as Strongly Agree. Item number 3 is "I was able to develop a deeper appreciation on the culture of the country." It has a mean of 3.62 and a standard deviation of 0.49 which can be interpreted as Strongly Agre.

However, the item number with the lowest mean is 8 which is "I was able to discover a problem from a visited destination in the educational tour/s. It has a mean of 3.44 and a standard deviation of 0.62 which can be interpreted as Agree.

According to Razdan (2021), "While on an educational tour/field trip students have the opportunity to have lively discussion in an informal set up. Experience gathered during a field trip to vineyards, hotels, tourist places, factories, breweries etc. are of immense benefit to students and help make learning fun and long lasting." The respondents reflected upon what happened in the educational tours like the experienced, assessing those tourism professionals, understand the purpose and objectives of the educational tours which the reflective observation is about.

The overall mean for this table 7 is 3.56 and is interpreted as Highly Effective.

TABLE8. Respondents Assessment of Educational Tours as Learning Tool in Terms of Abstract Conceptualisation

\begin{tabular}{|c|c|c|c|}
\hline Abstract Conceptualisation & Mean & Std.Dev & Interpretation \\
\hline 1. I realized how diverse their culture was. & 3.64 & 0.57 & strongly agree \\
\hline 2. I was able to compare the different types of attractions. & 3.56 & 0.59 & strongly agree \\
\hline 3. I was able to analyze their transportation system. & 3.60 & 0.53 & strongly agree \\
\hline 4. I was able to differentiate their religion. & 3.66 & 0.53 & strongly agree \\
\hline $\begin{array}{l}\text { 5. I have assessed the theory/concept that I've learned from the } \\
\text { classroom in the educational tour/s. }\end{array}$ & 3.51 & 0.56 & strongly agree \\
\hline $\begin{array}{l}\text { 6. I was able to develop my attitude or skill because of the } \\
\text { educational tour/s. }\end{array}$ & 3.56 & 0.57 & strongly agree \\
\hline 7. I was further motivated to learn because of the educational tour/s. & 3.68 & 0.47 & strongly agree \\
\hline 8. I was able to connect the educational tour/s with the tour journal. & 3.57 & 0.52 & strongly agree \\
\hline 9. I was able to use educational tour/s as a learning tool. & 3.68 & 0.47 & strongly agree \\
\hline $\begin{array}{l}\text { 10.I was able to relate the educational tour/s with the problems of the } \\
\text { society. }\end{array}$ & 3.59 & 0.57 & strongly agree \\
\hline Overall mean & \multicolumn{2}{|c|}{3.60} & highly effective \\
\hline
\end{tabular}

3.50-4.00 Strongly Agree / Highly Effective, 2.50-3.49 Agree / Effective, 1.50-2.49 Disagree / Somewhat effective, 1.00-1.49 Strongly disagree / Not effective

The table 8 shows the Respondents Assessment of Educational Tours as Learning Tool in Terms of Abstract Conceptualisation. In terms of Abstract Coneptualisation, two item numbers have the same highest mean and they are item number 7 and 9. Item number 7 is "I was further motivated to learn because of the educational tour/s" and item number 9 is "I was able to use educational tour'/s as a learning tool." Both item numbers have a mean of 3.68 and a standard deviation 0.47 which can be interpeted as Strongly Agree. The next item number is 4 which is "I was able to differentiate their religion" and it has a mean of 3.51 with a standard deviation of 0.56 which can be interpreted as Strongly Agree.

However, the item number with the least mean is 5 which is "I have assessed the theory/concept that I've learned from the classroom in the educational tour/s" and it has a mean of 3.51 with a standard deviation of 0.56 which can be interpreted as Strongly Agree. 
Educational Tours as a Learning Tool to the Third Year Tourism Students of De La Salle UniversityDasmarinas

According to Atlantis (2018), "Coming up with solutions makes them innovative thinkers. When learning is accompanied by fun, excitement, and enjoyment, it stops being burdensome and boring, and students learn as a part of their natural growing up process." The respondents were able to perform abstract conceptualisation after the educational tour making them more knowledgeable and experienced.

The overall mean for table 7 is 3.60 which can be interpreted as Highly Effective.

TABLE9. Significant Difference between Gender and the Respondents Assessment of Educational Tours with the Experiential Learning Theory (T-test)

\begin{tabular}{|c|c|c|c|c|c|c|c|}
\hline & Gender & Mean & \begin{tabular}{|l} 
Std. \\
Deviation
\end{tabular} & t-comp & P-value & Decision & Interpretation \\
\hline $\begin{array}{l}\text { Active } \\
\text { Experimentation }\end{array}$ & $\begin{array}{l}\text { MALE } \\
\text { FEMALE }\end{array}$ & $\begin{array}{l}3.5712 \\
3.5736\end{array}$ & $\begin{array}{l}.41837 \\
41004\end{array}$ & -0.030 & 0.976 & $\begin{array}{l}\text { Failed } \\
\text { reject Ho }\end{array}$ & $\begin{array}{l}\text { There is no } \\
\text { to significant difference }\end{array}$ \\
\hline $\begin{array}{l}\text { Concrete } \\
\text { Experience }\end{array}$ & $\begin{array}{l}\text { MALE } \\
\text { FEMALE }\end{array}$ & $\begin{array}{l}3.6346 \\
3.6604\end{array}$ & $\begin{array}{l}.34860 \\
41433\end{array}$ & -0.344 & 0.731 & $\begin{array}{l}\text { Failed } \\
\text { reject Ho }\end{array}$ & $\begin{array}{l}\text { There is no } \\
\text { to significant difference }\end{array}$ \\
\hline $\begin{array}{l}\text { Reflective } \\
\text { Observation }\end{array}$ & $\begin{array}{l}\text { MALE } \\
\text { FEMALE }\end{array}$ & $\begin{array}{l}3.5885 \\
3.5396\end{array}$ & $\begin{array}{l}38687 \\
44217\end{array}$ & 0.602 & 0.549 & $\begin{array}{l}\text { Failed } \\
\text { reject Ho }\end{array}$ & $\begin{array}{l}\text { There is no } \\
\text { to significant difference }\end{array}$ \\
\hline $\begin{array}{l}\text { Abstract } \\
\text { Conceptualization }\end{array}$ & $\begin{array}{l}\text { MALE } \\
\text { FEMALE }\end{array}$ & $\begin{array}{l}3.6250 \\
3.5849\end{array}$ & $\begin{array}{l}.37200 \\
.45251\end{array}$ & 0.495 & 0.621 & $\begin{array}{l}\text { Failed } \\
\text { reject Ho }\end{array}$ & $\begin{array}{l}\text { There is no } \\
\text { to significant difference }\end{array}$ \\
\hline Overall & $\begin{array}{l}\text { MALE } \\
\text { FEMALE }\end{array}$ & $\begin{array}{l}3.6048 \\
3.5896\end{array}$ & $\begin{array}{l}.34733 \\
.38632\end{array}$ & 0.212 & 0.833 & $\begin{array}{l}\text { Failed } \\
\text { reject Ho }\end{array}$ & $\begin{array}{l}\text { There is no } \\
\text { to significant difference }\end{array}$ \\
\hline
\end{tabular}

Table 9 shows the result on the significant difference between gender and the respondents' assessment of educational tours with the experiential learning theory using T-test. The result shows that gender is not a factor when it comes to the respondents assessment of educational tours as a learning tool because all the of p-value was more than the significance level of 0.05 .

The results reflect that there is no significant difference with the gender of the respondents and their assessment of educational tours as a learning tool because gender is not a factor to consider when assessing the effectiveness of educational tours. According to a NEA Member Benefits (n.d.), students learn much from the educational tours regardless of their gender.

TABLE10. Significant Difference Between Section and the Respondents Assessment of Educational Tours with the Experiential Learning Theory (ANOVA)

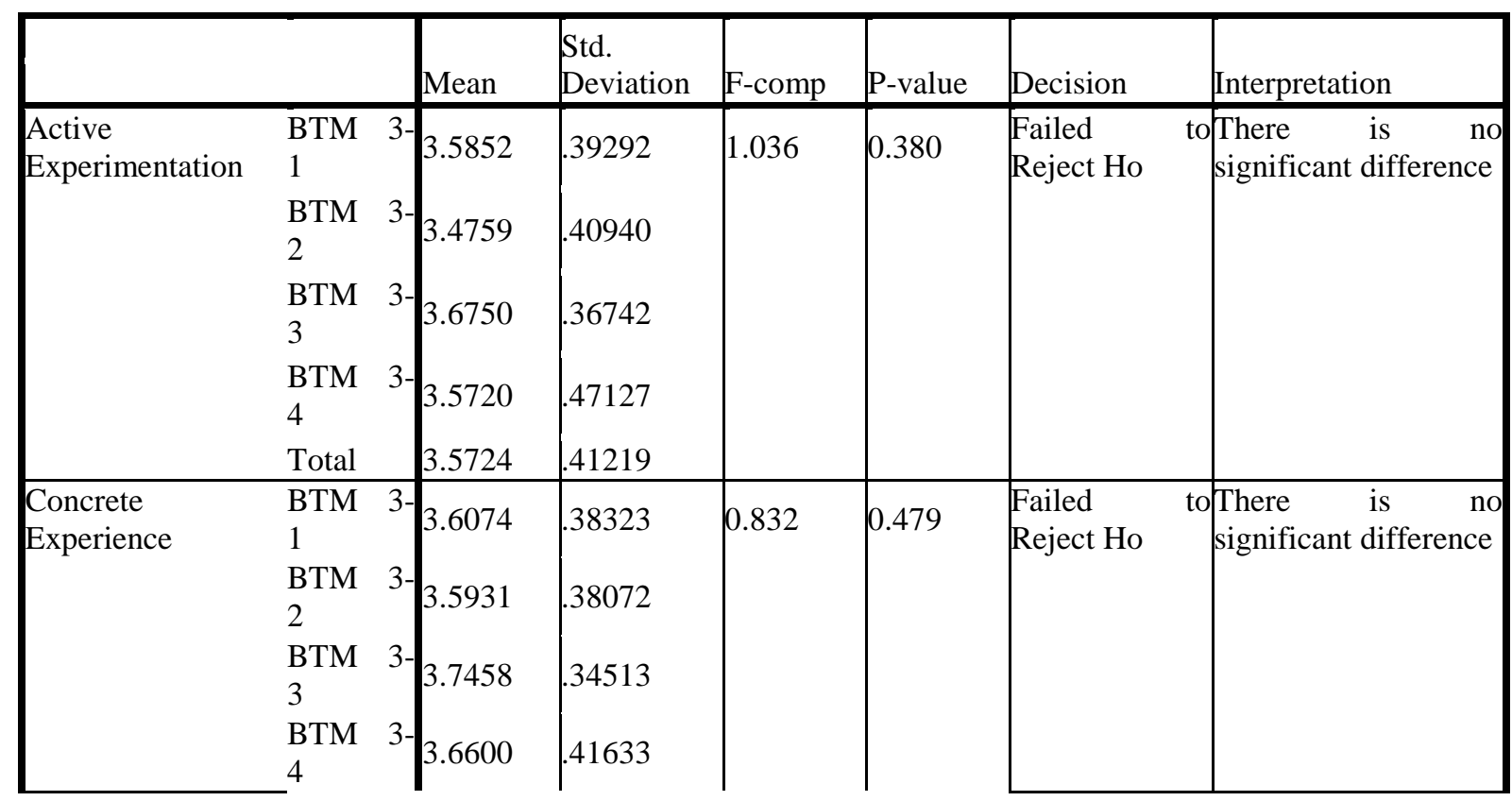


Educational Tours as a Learning Tool to the Third Year Tourism Students of De La Salle UniversityDasmarinas

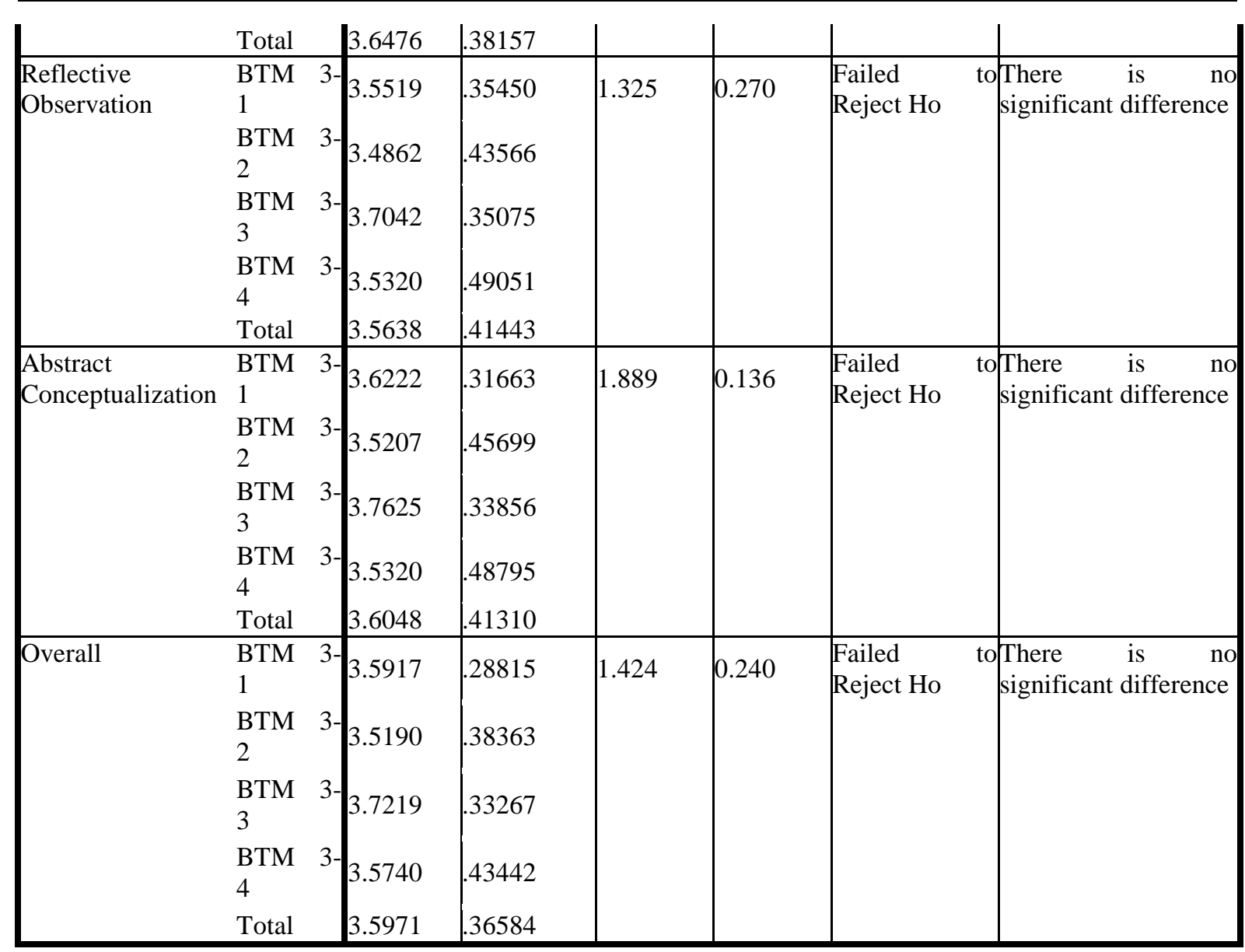

Table 10 shows the result on the significant difference between section and the respondents' assessment of educational tours with the experiential learning theory using ANOVA. The result shows that section is not a factor when it comes to the respondents assessment of educational tours as a learning tool because all the of $p$-value was more than the significance level of 0.05 .

The results reflect that there is no significant difference with the section of the respondents and their assessment of educational tours as a learning tool because section is not a factor to consider when assessing the effectiveness of educational tours. The respondents consider educational tours as a highly effective learning tool, regardless of their section.

TABLE11. Significant Difference Between Monthly Family Income and the Respondents Assessment of Educational Tours with the Experiential Learning Theory (ANOVA)

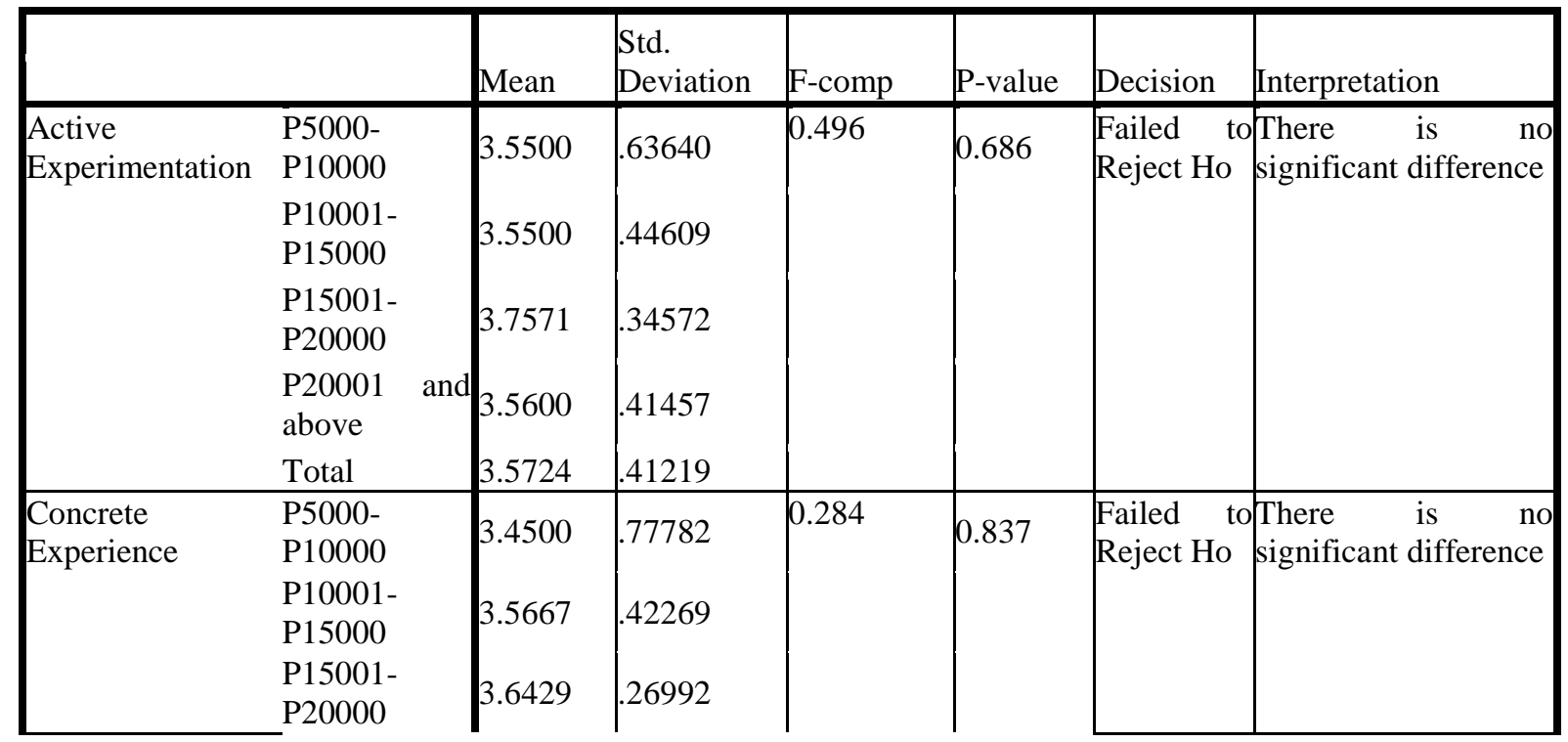


Educational Tours as a Learning Tool to the Third Year Tourism Students of De La Salle UniversityDasmarinas

\begin{tabular}{|c|c|c|c|c|c|c|c|}
\hline & $\begin{array}{l}\text { P20001 and } \\
\text { above } \\
\text { Total }\end{array}$ & $\begin{array}{l}3.6578 \\
3.6476\end{array}$ & $\begin{array}{l}38336 \\
.38157\end{array}$ & & & & \\
\hline $\begin{array}{l}\text { Reflective } \\
\text { Observation }\end{array}$ & $\begin{array}{l}\text { P5000- } \\
\text { P10000 } \\
\text { P10001- } \\
\text { P15000 } \\
\text { P15001- } \\
\text { P20000 } \\
\text { P20001 and } \\
\text { above } \\
\text { Total } \\
\end{array}$ & $\begin{array}{l}3.5000 \\
3.4167 \\
3.5286 \\
3.5778 \\
3.5638\end{array}$ & $\begin{array}{l}70711 \\
58109 \\
.36839 \\
.40635 \\
.41443 \\
\end{array}$ & 0.313 & 0.816 & $\begin{array}{l}\text { Failed to } \\
\text { Reject Ho }\end{array}$ & $\begin{array}{l}\text { There is no } \\
\text { significant difference }\end{array}$ \\
\hline \begin{tabular}{|l|} 
Abstract \\
Conceptualization \\
\\
\end{tabular} & $\begin{array}{l}\text { P5000- } \\
\text { P10000 } \\
\text { P10001- } \\
\text { P15000 } \\
\text { P15001- } \\
\text { P20000 } \\
\text { P20001 and } \\
\text { above } \\
\text { Total } \\
\end{array}$ & $\begin{array}{l}3.5000 \\
3.5167 \\
3.6143 \\
3.6122 \\
3.6048\end{array}$ & $\begin{array}{l}70711 \\
49967 \\
30783 \\
41539 \\
.41310 \\
\end{array}$ & 0.141 & 0.935 & $\begin{array}{l}\text { Failed to } \\
\text { Reject Ho }\end{array}$ & $\begin{array}{l}\text { There is no } \\
\text { significant difference }\end{array}$ \\
\hline Overall & $\begin{array}{l}\text { P5000- } \\
\text { P10000 } \\
\text { P10001- } \\
\text { P15000 } \\
\text { P15001- } \\
\text { P20000 } \\
\text { P20001 and } \\
\text { above } \\
\text { Total }\end{array}$ & $\begin{array}{l}3.5000 \\
3.5125 \\
3.6357 \\
3.6019 \\
3.5971\end{array}$ & $\begin{array}{l}70711 \\
.46871 \\
27908 \\
.36380 \\
.36584 \\
\end{array}$ & 0.181 & 0.909 & $\mid \begin{array}{l}\text { Failed to } \\
\text { Reject Ho }\end{array}$ & $\begin{array}{l}\text { There is no } \\
\text { significant difference }\end{array}$ \\
\hline
\end{tabular}

Table 11 shows the result on the significant difference between monthly family income and the respondents' assessment of educational tours with the experiential learning theory using ANOVA. The result shows that monthly family income is not a factor when it comes to the respondents assessment of educational tours as a learning tool because all the of $p$-value was more than the significance level of 0.05 .

The results reflect that there is no significant difference with the monthly family income of the respondents and their assessment of educational tours as a learning tool because monthly family income is not a factor to consider when assessing the effectiveness of educational tours. According to a NEA Member Benefits (n.d.), students learn much from the educational tours regardless of their socioeconomic status and monthly family income.

\section{CONCLUSION}

The result of the study shows that there more female students than male students who went on the educational tours. There were 53 female students (50.48\%) and 52 male students (49.52\%). When it comes to section, BTM 3-2 had the most number of students who went to the educational tours with a number of 29 students (27.62\%). While BTM 3-1 had 27 students (25.71\%), BTM 3-3 had 24 students $(22.86 \%)$, and lastly, BTM 4-3 had 25 students $(23.81 \%)$. Most of the respondents had a monthly family income of 20,001 Pesos and above with a frequency of 90 and a percentage of $85.71 \%$.

Based on the findings of the study, the researchers found that there is no significant difference between the demographic profile of the respondents such as gender, school section, educational tours joined and family monthly income and their assessment of the effectiveness of educational tours as a learning tool. Regardless of the respondents' demographic profile, they have the same assessment on the effectiveness of educational tours as highly effective. All the respondents agree that educational tours are a highly effective learning tool. 
The findings of the study show that $3^{\text {rd }}$ year Tourism management students strongly agree that educational tours are a highly effective learning tool in terms of Active Experimentation, Concrete Experience, Reflective Observation and Abstract Conceptualisation. The respondent's assessment of Educational Tours as Learning Tool in terms of Active Experimentation testified that the skills, abilities and experienced that they have acquired in the educational tours were applied outside the classroom setting and to their chosen future careers. The respondent's assessment of educational tours as learning tool in terms of Concrete Experience showed that the students visited different attractions, observed different tourism careers and establishments, experienced different transportation systems, interacted with local and different sections while having fun during the educational tours The respondent's assessment of educational tours as learning tool in term of Reflective Observation revealed that the students understood the purpose and objective of the educational tours, evaluated the tourism resources, assessed different tourism profession, reflected about educational tours and the visited attractions, reflected the skills and attitudes of those in the tourism industry. The respondent's assessment of educational tours as a learning tool in terms of abstract conceptualisation illustrated how the students were compared different types of attractions, assessed the theory/concept from classroom into educational tours, developed attitude or skills. further motivated to learn, relate educational tours with the problem of the society and lastly use educational tour as a learning tool.

Based on the findings the researchers concluded that educational tours are truly a highly effective learning tool to the third year tourism students. The students view the educational tours as highly effective regardless of their demographic profile such as gender, section, educational tours joined and monthly family income. This goes to show that the students learn from educational tours no matter what their gender, section, educational tours joined and monthly family income are. The students learn so much more outside the classroom, during their educational tours and they have fun while doing so.

\section{OUTPUT}

The researchers recommend that the De La Salle University-Dasmarinas should use the South Korea tour as a foundation for the potential educational tours of the Tourism Management student because the survey questionnaires showed more students participated the South Korea tour compared to Taiwan tour. The college must organize tours that will expose students to experience foreign culture, historical sites, riding different modes of transportation, more activities that will engage the students to reflect and interact with the locals, seminars that would emphasize on the skills, and attitude of those in the tourism profession in that educational tour, allowing the students to use their knowledge when planning their own itinerary, it should be an affordable educational tour for students that have limited financial resources.

\section{REFERENCES}

[1] A.Ahad,. (2017). A Study of the Application of Kolb's Theory of Experiential Learning and Differential Type of Studio in Teaching of Architecture. International Journal of Innovative Research in Science, Engineering and Technology, 6(3), 3630- 3634. DOI:10.15680/IJIRSET.2017.0603118 .

[2] Atlantis. (2018). 5 Benefits of Educational Tours. https://atlantisresearch.in/5-benefits-educational-tours/

[3] Barton, Tara. (2020). Using Experiential Learning Theory To Make A Difference In The Future Of Education. Retrieved from https://servelearn.co/blog/using-experiential-learning-theory-to-make-adifference-in-the-future-of-education/?fbclid=IwAR13w0nuHetKM0k_a_4nWklExEIhy--pmGkaw8fpCP 4QImlW7qomLA0_H58 [3]. R. Benato and A. Paolucci, EHV AC Undergrounding Electrical Power. Performance and Planning. New York: Springer, 2010.

[4] Bleich, Corey. (n.d.). 5 Benefits Of Experiential Learning In The Workplace. Retrieved from https://www.edgepointlearning.com/blog/benefits-of-experiential-learning/

[5] Cao Cu Giac, Tran ThiGai, and PhanThiThanh Hoi, (2017) "Organizing the Experiential Learning Activities in Teaching Science for General Education in Vietnam." World Journal of Chemica Education, vol. 5, no. 5: 180-184. doi: 10.12691/wjce-5-5-7. in Higher Education 12(2)ISSN : 1985-5826 Doi.org/10.1080/03043797.2017.1402864

[6] Dunsmore (2017). 15 Reasons Why You Should Visit South Korea at Least Once in Your Lifetime from https://theculturetrip.com/asia/south-korea/articles/15-reasons-why-you-should-visit-south-korea-at-leastonce-in-your-lifetime/

[7] Educating Adventure (n.d.). Why is experiential learning important? https://www.easchooltours.com/ blog/experiential-learning-learn-through-experience 
[8] F. Widyastuti, R. M. Probosari, S. Saputro, S. Soetikno, \& S. Sajidan. (2019). Teachers viewpoints of teaching science using experiential learning related to environmental issues. AIP Conference Proceedings 2194, (020140)1-5. https://doi.org/10.1063/1.5139872

[9] Gorghiu, G. \&Santi, E. (2016). Applications of Experiential Learning in Science Education Non-Formal Contexts. ICEEPSY 2016 International Conference on Education and Educational Conference. 321-326. DOI: $10.15405 /$ epsbs.2016.11.33

[10] H. Li, Ochsner, A. \& Hall, W. (2017). Application of experiential learning to improve student engagement and experience in a mechanical engineering course. European Journal of Engineering Education, 44(3), 283-293.

[11] Idris, F., Din, W.M., Tajuddin, M. (2020). Adapting Kolb's experiential learning cycle in enhancing attitude and skills among undergraduate through volunteerism. ASEAN Journal of Teaching \& Learning in Higher Education 12(2)ISSN : 1985-5826

[12] Kerner, Robert. (2018). Five advantages of experiential learning. Retrieved from https://www.northwell .edu/news/five-advantages-of-experiential-learning.

[13] Kurt, Serhat. (2020). Kolb's Experiential Learning Theory \& Learning Styles. Retrieved from https:// educationaltechnology.net/kolbs-experiential-learning-theory-learning-styles/?fbclid=IwAR04293haX8F EaRxajDPYociQR2YIMYiREhr9OM9BD2XwK_o6OISY_6T2fA

[14] Lilia Gomez-Lanier. (2017). The Experiential Learning Impact of International and Domestic Study Tours: Class Excursions That Are More Than Field Trips. 29 1, 129-144. https://files.eric.ed.gov/fulltext /EJ1135842.pdf

[15] McPherson-Geyser, G., de Villiers, R., \&Kavai, P. (2020). The Use of Experiential Learning as a Teaching Strategy in Life Sciences. International Journal of Instruction, 13(3), 877-894. https://doi.org/10.29 333/iji.2020.13358a

[16] McLeod, Saul. (2017). Kolb's Learning Styles and Experiential Learning Cycle. Retrieved from https://www.simplypsychology.org/learning-kolb.html?fbclid=IwAR1TO5b4050IVIPg8DFE-y-nwSZKF rw7wVNXc0NgI7QH-iO0uMG6_lVzqv4

[17] McPheat, Sean. (2017). What Are KOLB's Learning Styles And What Do They Mean?. Retrieved from https://www.skillshub.com/what-are-kolbs-learningstyles/?fbclid=IwAR0qzObFxgCDtiIOrlqURBK3JWz5O4Mp2JpNklcSdMv0US_6nCjQAMbxXbU

[18] NEA Member Benefits. (n.d.). How Field Trips Boost Students' Lifelong Success. https://www.neamb. com/work-life/how-field-trips boost-students-lifelong-success

[19] PSA (2018). Final 2018 Family Income and Expenditure Survey (FIES) Press Release and 2018 FIES Final Report from https://psa.gov.ph/content/final-2018-family-income-and-expenditure-survey-fies-pressrelease-and-2018-fies-final

[20] Razdan, T.K. (2021). Educational Tours or Field Trips as a Benefit to Students. https://theknowledge review.com/educational-tours-or-field-trips-as-a-benefit-to-students/\#: :text=Educational\%20Tour\%2FFi eld $\% 20$ Trips $\% 20$ also, developing\%20overall $\% 20$ personality $\% 20$ of $\% 20$ students.

[21] UNWTO (2020). WOMEN'S EMPOWERMENT AND TOURISM from https://www.unwto.org/genderand-tourism

[22] Wingston, Sue. (2020). The Benefits of Experiential Learning. Retrieved from https://www.eaglesflight. $\mathrm{com} / \mathrm{blog} / \mathrm{benefits-of} \mathrm{experiential-learnin}$

Citation: Jackqueline E. Uy, et.al. "Educational Tours as a Learning Tool to the Third Year Tourism Students of De La Salle University- Dasmarinas". International Journal of Research in Tourism and Hospitality (IJRTH), vol 7, no. 1, 2021, pp. 32-45. doi: https://doi.org/10.20431/2455-0043.0701004.

Copyright: () 2021 Authors. This is an open-access article distributed under the terms of the Creative Commons Attribution License, which permits unrestricted use, distribution, and reproduction in any medium, provided the original author and source are credited. 